\title{
From Self Banishing Life to Life Banishing Self: The Prominent Causality and Lady Macbeth's Tragic Downfall
}

\author{
Md. Abu Saleh Nizam Uddin*
}

\begin{abstract}
Lady Macbeth of Macbeth is one of the most widely discussed characters created by Shakespeare. In the drama, just after Macbeth's disclosure to her as regards the witches' prophecy, she decides to pursue the shortest way to reach her goal within the shortest possible time. She instantly plans to kill King Duncan to enable Macbeth to ascend the Scottish throne. In this process she ultimately plans to have her share in power and prestige with her husband. To prepare herself for the horrible act of the murder, Lady Macbeth completely rejects natural and vital contents and functions of her soul or self. It is the dreadful banishment of self from life. It is tantamount to a manifold distortion of her feminine and human soul. She succeeds in her attempt only to experience the unbearable weight of regret and remorse that finally causes her to punish herself terribly in her own morose conditions which is life's banishment from self, a downfall of colossal magnitude. This article aims at understanding the significance of this issue by studying the functioning of Lady Macbeth's soul from the perspective of philosophy. This will also be done and by juxtaposing her with characters of similar nature from some of the great literary works.
\end{abstract}

Life of an individual is naturally happy if the soul or self is allowed its contents and functions, that is, if self remains in life. For Descartes self is mind which "has the capacity for reasoning, remembering, denying, has free will and is morally responsible for its action"(Lavine 120). This is how the nature of thoughts and activities of a person is determined by his consciousness that originates in self. Now the truth can be uttered that contents and functions of self should be at the

\footnotetext{
${ }^{*}$ Lecturer, Dept. of English Language and Literature, International Islamic University Chittagong
} 
centre when conduct of a person is discussed. Here inevitable focus on self or soul leads to life because life is made up of those self-directed thoughts and actions. For Hogben and Haldane, soul, with its consciousness, is an integral part of life ("Life").

From this important point of view of self and life, role of Lady Macbeth in Macbeth is worth-noticing. Lady Macbeth, nourishing intense greed for power and prestige, causes complete banishment of self from her life. This banishment is featured by her isolation from vital nature, reluctance in living a normal conjugal life, rejection of the natural qualities determined by gender, eagerness to have psychological gender transformation to achieve cruelty, willingness to destroy new generation and mankind and wish to have aid from evil powers opposing religion. This is unusually extreme empowerment of the irrational part of the soul. In response, life pays with the same coin. It banishes itself from self. Lady Macbeth dies a miserable death.

King Duncan, as a token of his gratitude to Macbeth, who has achieved victory over the rebel MacDownald, sets out to pay a visit to Macbeth's castle at Iverness. As he, Banquo and others reach near their destination, they notice the birds Martin nesting nests everywhere in Macbeth's castle. There they enjoy the heavenly sweetness of the air. Obviously it is a charming spectacle of nature. This attracts the attention of King Duncan and Banquo. Duncan says,

This castle hath a pleasant seat; the air

Nimbly and sweetly recommends itself.

Unto our gentle senses. (1.6.1-3)

Similar is the reaction of Banquo. He delights in giving outlet to his feeling. He says,

This guest of summer,

The temple-haunting martlet, does approve

By his loved mansionary that the heaven's breath,

Smells wooingly here, No jutty, frieze.

Buttress, nor coign of vantage but this bird.

Hath made his pendent bed and procreant cradle;

Where they most breed and haunt, I have observed.

The air is delicate. (1.6.4-10)

Such observation and expression of Duncan and Banquo are worth noticing though there are ironical implications. To A.C. Bradley, their 
innocence is as bright as sunlight. He says,

In the whole drama the sun seems to shine only twice; first, in the beautiful but ironical passage where Duncan sees the swallows flitting round the castle of death; and, afterwards, when at the close the avenging army gathers to rid the earth of its shame. (292)

Both of them are innocent and full of human feelings which is why the scene sheds light. This imagery of cheerful and beautiful birds at Iverness stands for sacred and traditionally valued guest-host realtionship. By feeling love for these birds, King Duncan and Banquo hint at their ardent adherence to the efficacy of guest-host relationship.

But Lady Macbeth is quite the opposite. Her contrast shown by the dramatist in her being away from the pleasant natural atmosphere outside her castle gives gesture to her reluctance to that sacred human relationship. It also hints at her ability to be malevolent if situation like materializing high ambition demands. This feature of Lady Macbeth contributes to the darkness of atmosphere in the drama. Thus she, according to the situation created by her ambitious husband, frantically acts to make Macbeth the king of Scotland. Conscience does not prick her as she expels it altogether from her life. Thus she thinks she makes a flawless plan to kill Duncan, and implement, it within less than twenty four hours' time. She boastfully says,

O never.

Shall sun that morrow see. $(1.5 .58-59)$

She has perhaps nurtured the thought that her life will be wonderfully happy by being the queen of the king Macbeth after Duncan is killed which is also a kind of ambition though not as intense as Macbeth's. If it had not been there in her besides her allegiance to her husband's will, she could not perhaps make such an accurate plan and had it executed within such a short period of time. This is also proved by the fact that she can remain remarkably calm and quiet even when the situation is too horrible immediately before killing Duncan. "To her, things remain at the most terrible moment precisely what they were at the calmest', (Bradley 327). To make her dominant impact on Macbeth more effective in committing the sinful murder of Duncan, she excludes from her mind the element of honour meant for the sacred guest-host relationship. 
In the drama we do not find Lady Macbeth's own name. It apparently means "She has pleasantly sacrificed her own identity and associated it with Macbeth's. Such is the extent of her love for her husband" (Choudhury 41, translation mine). Actually it may not be so. There is scope to be skeptic when she is termed as a loving wife. Macbeth, one of the Generals of Scottish army, is more powerful and more influential as his contribution in the battlefield exceeds even Banquo's. As acknowledgement for his deeds, he is conferred the title Thane of Cawdor upon his present one, the Thane of Glamis. King Duncan holds him in great esteem which is proved by Macbeth's words,

He hath honoured me of late, and I have bought

Golden opinions from all sorts of people (1.7.32-33)

But at the same time Macbeth has dormant greed for power. Clearly, for Lady Macbeth, there is nobody else who has as much chance as Macbeth to snatch the royal power from Duncan. So Lady Macbeth perhaps feels she is the wife of the fittest person Macbeth. She may not behave like greedy and corrupt Goneril and Regan of King Lear. But she, before Duncan's murder takes place, does not seem to have any problem in being the queen of a king who is a murderer. It again proves her personal ambition for which ambitious Macbeth is the right person. Her love for him is also for the fact that Macbeth is the best medium that can function according to her wish. At this point she resembles Eustecia Vye of Hardy's Return of the Native, who struggles very hard to have a medium either in the shape of Clym Yeobright or Wildeve to reach and settle in the fashionable city of Paris.

Lady Macbeth rebukes and advises her husband to play deception for the smooth attainment of their goal. She says,

Your face, my thane, is as a book where men May read strange matters. To beguile the time, Look like the time; bear welcome in your eye, Your hand, your tongue: look like th' innocent flower, But be the serpent under't. (1.5.60-64)

Lady Macbeth says that her sense of honour for King Duncan is "deep and broad" (1.6.18). On hearing her words, Duncan's joy knows no bounds. In her, pretension and seriousness are hard to be distinguished. Such a power hungry lady can play trick even with her husband. This is ensured by another fact. If she had true love for Macbeth as a person 
and as her husband, she would not wish to "chastise" (1.5.25) Macbeth even orally to remove his scruple and fear. She could not use the words "a coward" (1.7.43) or "the poor cat i' th' adage" (1.7.45) while she herself is a Countess with sound cultural sense, and Macbeth, besides being her husband, a distinguished person in the country. Terry Eagleton considers her to be "a 'bourgeois' feminist who strives to outdo in domination and virility the very male system which dominates her" (50). Therefore, she fails to anymore belong to the class of women who are termed as loving wives. This feature of her person proves to be instrumental in exercising extreme dominance over her husband to mould him into making her dream come true.

Lady Macbeth's eyes, until Macbeth reaches the supreme power of the country, are towards kingship, not towards Macbeth. After occupying the kingship, Macbeth's eyes are always towards securing his position, not towards Lady Macbeth. She is the initiator here. Thus, at one stage, by excluding from herself the concept of happy conjugal life in the truest sense of the term, Lady Macbeth suffers indescribable mental agony and dies a miserable death.

To Sigmund Freud, this terrible comment is "a brief epitaph" (40). It is the testimony that since the time of occupying kingship, Macbeth has been too busy to maintain his normal attachment with his wife. This attitude of Macbeth takes the shape of negligence for her then. Its effect on Lady Macbeth is severe. Sigmund Freud views "she becomes all remorse and he all defiance"(44). Macbeth's negligence of Lady Macbeth from the moment of his usurpation of the kingship is similar to her artificial devotion to him that was more observed at the beginning of the drama.

It is very natural that as a mother a woman bears profound love and affection for her issues. In this regard her feeling is far deeper than her male counterpart. If it is checked, she can go so far as to be revengeful. Clytemnestra, in Aeschylus's Agamemnon, kills her husband Agamemnon to avenge the murder of her innocent daughter Iphigenia. It is the stronger reason. Severely grief-stricken at losing the most loving object of her life, she stabs her husband again and again until he dies. Then she expresses her satisfaction saying:

When on my virgin daughter

His savage sword descended,

My tears in river ran; 
If now by savage sword-thrust

His ageing days are ended,

Let shame and conscience ban

His boasts, where he pays forfeit

For wrong his guile began.

(1525-1537)

Clytemnestra does not tolerate any obstacle to stand between her and her child with whom she has connection through umbilical cord. But Lady Macbeth does. Rather she will not tolerate any obstacle to stand between her share in Macbeth's possible kingship and herself, be it her child feeding at her breasts. She says:

I have given suck and know

How tender 'tis to love the babe that milks me:

I would, while it was smiling in my face,

Have plucked my nipple from his boneless gums

And dashed the brains out, had I so sworn

As you have done to this. (1.7.54-59)

Sometimes it might appear that these words of inhuman cruelty Lady Macbeth utters are only to motivate Macbeth though inwardly she is affectionate like other mothers. But it is not right. First, in her she nourishes no love for her child. It is authenticated by the fact that she does not bother when the witches make no prophecy about kingship for her children. In her life children are not at all important in comparison to having supreme power and prestige by becoming queen when Macbeth ascends the throne. That children are less important to her is more emphasized by the unavailability of their names in the drama while we do know the names of Duncan and Banquo's sons. Second, she says that she herself would kill Duncan if Duncan's face did not resemble her father's. She unknowingly ridicules the fatherdaughter relationship since she is not killing a person by herself as he looks like her father, but she is having him killed by someone else. Bradley views, "The probability that the old king will sleep soundly after his long journey to Iverness is to her simply a fortunate circumstance; but one can fancy the shoot of horror across Macbeth's face as she mentions it" (327). To her, the sleeping Duncan who resembles her father and evokes a ray of her humanity is also a fish whom Macbeth as a cat hesitates to eat. This familiar and prosaic illustration "the poor cat in the adage" she uses to force Macbeth to the task as he is confused to kill Duncan. This is sheer cruelty of Lady 
Macbeth. With this cruelty, if not with her own hand, she could very easily have her child killed when situation demanded. She is unlike Clytemnestra. She is unlike other women. She sends her motherly affection to an everlasting exile from her soul. This terrible monstrosity helps her to face no difficulty in making her plan and executing it within a very short period of time.

Lady Macbeth rather wishes to adopt male characteristics as she feels that she lacks in the courage of a man to commit homicide. The birth of a child indicates a man's prior role in begetting the child inside the womb of his wife. Thus, the roles to be played by the husband and the wife in this regard are set by the law of nature. This is a law related to the physical features of human beings. But violating this law, at least mentally, Lady Macbeth who has already succumbed or could succumb to this law physically by embracing motherhood, tries to play the role of a husband as she wishes to pour her soul inside her husband Macbeth with a view to stopping him from being sympathetic which is important for killing Duncan to ascend the Scottish throne. She says in a soliloquy:

Hie thee hither,

That I may pour my spirits in thine ear (1.5.23-24)

She appeals to the evil spirits, "unsex me" (1.5.39). She wishes to go through a psychological gender transformation, so that the instinctive softness of a female can not be an impediment in executing her horrible plan of killing Duncan. This point is further clarified as Sigmund Freud observes, "She is ready to sacrifice even her womanliness to her murderous intention, without reflecting on the decisive part which this womanliness must play when the question afterwards arises of preserving the aim of her ambition, which has been attained through a crime" (39). Thus Lady Macbeth quits the world of women and psychologically becomes a man.

Also, she even quits the world of mankind. When her male disposition is found to be located in her female body, its likeness can be drawn with Banquo's description of the witches which states that witches depict both male and female characteristics.

you should be women,

And yet your beards forbid me to interpret

That you are so. (1.3.43-45) 
Thus she resembles witches. To support this view her isolation from other human beings, a common trait of the witches, can be noticed. Her isolation is perceived almost from the beginning of the drama when she receives the news of witches' prophecy. She is to be looked at as Christopher Mills does in his essay "The Relationship between Macbeth and Lady Macbeth" as "being the first character to enter alone hinted at her future isolation from humanity and society" (54). Each inch of the total length of the drama reveals her complete isolation.

Lady Macbeth pours her "spirits" into Macbeth. With its aid Macbeth manifests his long suppressed ambition and becomes quite capable of shedding blood if necessary. And as he feels it necessary for his kingship, he kills or wants to destroy the new generation (Fleance, children of Macduff, young Siward) and the parents (Duncan, Banquo and Lady Macduff). Whatever the reason is, his position is against the very structure of human relationship and the race of mankind itself. As Macbeth takes this position, Lady Macbeth certainly has her contribution in it which readers easily figure out. Lady Macbeth herself feels this way. Thus the feeling is there that she is against mankind. And this is how Macbeth becomes the most horrific of all Shakespearean dramas (Choudhury 39, translation mine). Lady Macbeth's voluntary inclusion of this awkward condition into her life makes her the lonely female in her own pole whereas all the other females of the world are to be found in another pole. It is a banishment she chooses for herself. Yet this facilitates her to take speedy measure to materialize her dreadful plan.

Lady Macbeth's standpoint is against the God when she appeals to the evil spirits to enable her to exchange "milk for gall" (1.5.46). Here "gall" is the substance she wants; "gall" that signifies evil. She does not want "milk" which signifies the God.

In the discussion of the opposition of religion, and consequent destruction or banishment of one essential element from self, Lady Macbeth can be placed beside Dr. Faustus of Doctor Faustus by Christopher Marlowe. Having excessive pride in his knowledge, Dr. Faustus wishes to practise necromancy or black art of magic which will establish his connection with the devil through whom he can acquire super-human powers. Thus he wants to enjoy life to the core for twenty four years. Therefore, ignoring "the Scriptures" (1.1.72) of the Good Angel, he voluntarily does blasphemy. He conjures in "the gloomy shadow of the night" (1.3.1) and wants that "the spirits are 
enforced to rise" (1.3.13). But the point to be noted here is that in this evil meditation Faustus inwardly confronts a debate between good and bad sides of his soul in the shape of Good Angel and Bad Angel. But in the case of Lady Macbeth, as she first comes to know about the prophecies from Macbeth, she straightforwardly prepares herself to kill Duncan. Besides, Faustus initiates his intended activities with the help of the evil power of Mephistophilis. But Lady Macbeth does it almost by herself by making the plan of killing Duncan. As she cannot do it all by herself, she wishes to have help from evil spirits. In a soliloquy, she evokes evil spirits saying,

Come, you spirits

That tend on mortal thoughts, unsex me here, And fill me from the crown to the toe top-full

Of direst cruelty; make thick my blood. (1.5.38-41)

This is how Faustus is an agent of evil whereas Lady Macbeth is agent provocateur. Despite having this differentiating trend, Lady Macbeth is identical with Faustus in opposing religion, in banishing this essential element from self.

Lady Macbeth wants the Spirits to make her normal blood thick, so that sympathy cannot flow in her mind. Thus she rejects sympathy, one form of charity essential in Christianity. Here this sympathy comprises morality and conscience as well. To Terry Eagleton Lady Macbeth "imagines an attack on the reproductive passages of her own body, on what makes her specifically female"(57). Dr. Faustus does not go that far. When he finds his blood curdling as he writes the deed with his blood to surrender his soul to Lucifer, he says, "My blood congeals, and I can write no more!" (2.1.62). This congealing of blood is the symbolic suggestion arising from a sense of morality and conscience. Thus he is startled though ulimately he rejects morality and religion. But Lady Macbeth, far from depicting startled approach, takes calculated steps; it is calculated because she clearly discerns the obstacle of compassion in her way of committing sinful murder. And she appeals to the evil spirits beforehand to block the passage of compassion by having her blood thickened. Obviously, Lady Macbeth's standpoint against compassion, a form of charity in Christianity, is deeper and stronger than Faustus' against morality and conscience as she shows a more organised approach. 
Lady Macbeth's severe mental sufferings take place within her. Seyton even gives the report "The queen, my Lord, is dead." (5.5.16). But in Faustus's case, the destruction is caused by a force called Mephistophilis, from outside his self. Though Faustus suffers the greater, it is worthwhile to observe Lady Macbeth's suffering which is the result of her rejection of religion to the extent of its entire banishment from life.

The story of Macbeth belongs to the 12th century.But it was written during the time of Renaissance which includes its pioneering figures like Niccole Machiavelli. The reason for raising this point is to see Lady Macbeth from the point of view of Machiavellianism or utilitarianism. Renaissance was the time when "High ambition was not considered a vice; rather it was a virtue" (Choudhury 44, translation mine). This "virtue" of "High ambition" was associated with Renaissance humanism that inspired shattering of the rigidities in the hierarchy of social order. "The perception began to develop that the new Renaissance humanistic mentality was breaking through the hierarchical rigidities of the existing social order" (Lavine 82). Thus, as a part of the fulfilment of the "High ambition", "Killing and bloodshed for occupying throne was not an unusual phenomenon at that time" (Choudhury 44) throughout whole Europe. This is how a utilitarian motif dominated which finally got manifested through Machiavelli's Prince in 1513. Prince is the book where "the drift of Machiavelli's thought is in the direction of equating the right with the expedient". Machiavelli opines that determining whether something is right or wrong should depend on its usefulness, which comes from a person's feeling that denies any impact of higher law. Machiavelli "recognized no higher law such as Acquinas had propounded but urged a thoroughly secular approach to politics" (Stumpf 197).

If these are the traits of Renaissance, Lady Macbeth perfectly matches with them. This is how she can be considered if Macbeth is looked at as a literary composition to have arrived after Machiavelli. Lady Macbeth turns out to be the glaring example of Machiavellianism or utilitarianism and figures out validity in the cruelest way of materializing her ambition of becoming Macbeth's "dearest partner of greatness" (1.5.9-10).

If Macbeth is deemed as a story of $12^{\text {th }}$ century, then again we must say that Lady Macbeth is a part of the society which was the long background of the Renaissance principle called Machiavellianism. If 
the culmination of utilitarian trend of mind was in Machiavellianism, Lady Macbeth belongs to its earlier stage. As a result she could not become a complete utilitarian for which she suffered for her action later in the drama. Thus, she is more or less a utilitarian or Machiavellian who banishes from self the issues of morality.

Besides bearing the trends of Machiavellianism, Lady Macbeth even exhibits features of bourgeois individualism. She is an individualist by being firmly grounded in her sense of individual freedom, by having her individuality assume supreme importance, and, thus, casting away ethical issues and traditional values while brooding over killing King Duncan. In other words, she has her inclination of free thinking. The decision to kill Duncan to have kingship for her husband while she will be the queen is not to please her husband only, rather it is to please herself as well. Here her own free thinking accelerates the fulfilment of her high ambition which coincidentally matches with her husband's. At the same time her actions can be identified as materialistic pursuits which permits to characterise her as a bourgeois. Thus she is a bourgeois individualist. Terry Eagleton says, "Like most of Shakespeare's villains, in short, Lady Macbeth is a bourgeois individualist, for whom traditional ties of rank and kinship are less constitutive of personal identity than mere obstacles to be surmounted in the pursuit of one's private ends" (49). But after the act of murder, she changes and meets mental disorder.

Here's the smell of the blood still; all the perfumes of Arabia will not sweeten this little hand. O, O, O. (5.1.42-43)

Her agonizing repentance commences and she turns out to be a nervous wreck. Both Machiavellian domain and the world of a bourgeois deny soul or self in life. Reaction is obvious in the form of the denial of life in self, and eventually Lady Macbeth has to commit suicide.

Lady Macbeth can also be compared with a blind dove which flies higher and higher not seeing the surroundings and the level of heigth it is reaching. In this way, she may be held as the embodiment of Bacon's view expressed in his essay "Of Ambition" included in Essays. Bacon says that an ambitious person is "like a seeled dove that mounts and mounts because he cannot see about him" (97). Lady Macbeth has concentrated only on her and her husband's higher positions ignoring her surroundings of society, human relationship, 
humanity, morality and spirituality. Here lies danger for her as it has been with the dove. Thus she meets her inevitable fall.

In order to bring Lady Macbeth into a philosophical discussion, Aristotle may be referred to. Each person is capable of doing both good and bad. This duel possibility of capability is associated with his person, not his body. His person is actually his soul. Thus his soul is the one and only centre which decides the nature of a person's character or morality. Aristotle's study of human soul in his theory of morality is rightly pointed out by Stumpf.

The soul is the form of the body. As such, the soul refers to the total person. Accordingly, Aristotle said that the soul has two parts, the irrational and the rational. The irrational part in turn is composed of two subparts, the vegetative and the desiring or "appetitive" parts. For the most part, these are "something contrary to the rational principle, resisting and opposing it". The conflict between the rational and irrational elements in man is what raises the problems and subject matter of morality. (93)

The rational elements in not trying to remove the legitimate king from the throne are resisted and opposed by "the vegetative and the desiring or appetitive parts" (93) of the souls of Macbeth and Lady Macbeth. It happens more in Lady Macbeth. Thus, when Macbeth initially falters to commit the cruel act, Lady Macbeth provides him with instigation and a sound plan utilizing a golden opportunity offered by innocent Duncan himself as he becomes guest in Macbeth's castle.

When the third witch ensures glory for Banquo's posterity saying "Thou shalt get kings", his soul performs an action that deserves high commendation (1.3.65). The particular kind of action implied here, if one has in mind Aristotle's analysis of the soul, is the rational control and guidance of the irrational parts of the soul (Stumpf 93). This is how he figures out the eventual entrapment in the prophecy of the weird sisters. He even tries to convince Macbeth, for whom kingship is predicted, not to do anything irrational or immoral that can be selfdestructive in the long run. In a sense his standpoint is against the sinister influence of the witches and Lady Macbeth upon Macbeth. He warns Macbeth about the "honest trifles" of the witches (1.3.124). 
Banquo's realization forms his thoughts. Predictably, he does not confine his pure thoughts within their frame. Bacon, in "Of Great Place" of Essays, says ". . . good thoughts (though God accept them) yet towards men are little better than good dreams, except they be put in act" (35-37, p.26). Undoubtedly, Banquo's good thoughts get translated into action. He conforms to Aristotle. Morality involves action, for nothing is called good until it is functioning (Stumpf 93). This quality of Banquo is called virtue. This virtue or morality at least enables Banquo to remain free from severe sufferings of Lady Macbeth and terrible tension and tragic death of Macbeth.

Unlike Banquo, Lady Macbeth fails to realize that happiness is "the intrinsic ends" to which other ends are "instrumental ends" (Stumpf 92). She hankers after usurpation of kingship which is, for her, "the golden round" (1.5.26). the "ornament of life" (1.7.42), and the like; and appreciates passionately the "sovereign sway and masterdom" (1.5.68). It is fatally unjust as Lady Macbeth deems power and prestige as the chief end of her life.

She stands apart from the code of morality. She utterly disregards the truth that happiness should be the goal of each individual, a vital and teleological finding by Aristotle, and it "is a working of the soul in the way of excellence or virtue" (Stumpf 94). She even opposes and unknowingly tortures the very structure of her human soul, an object of nature, far from realizing horrible flaws in her actions. Marilyn French opines, ". . . Lady Macbeth has violated natural law" (16). After Macbeth has occupied the kingship and starts committing murder to secure it, she returns to her conscience. She dolefully says,

Nought's had, all's spent

Where our desire is got without content.

'Tis safer to be that which we destroy

Than by destruction dwell in doubtfull joy. (3.2.4-7)

But soon this conscience turns disorderly by the sense of her committed sin. Actually, she has already reached the point of no return and her repentance can not restore normal condition to her mind. Rather this repentance, together with the profound self-inflicted injury to her soul, leads her to hell on earth. She pays the price for "transgression, the ceaseless surpassing of limits", as viewed by Eagleton in the form of sleep-walking, complete mental breakdown and subsequent miserable death (48). 
The components that make up the self of a human being are denied by Lady Macbeth. Miserably enough, she even destroys them all. Consequently, her self makes an exit from life. Retaliation of life is easily predictable. She meets a tragic catastrophe, an exit of life from self.

\section{Works Cited}

AESCHYLUS. The Oresteian Trilogy. trans. Philip Vellacott. Ed. Betty Radice. London, England: Penguin, 1988.

BACON, FRANCIS. Bacon's Essays, Chennai. India: Macmillan, 2004.

BRADLEY, A.C. Shakespearean Tragedy. 3rd ed. London: Macmillan, 2000.

CHOUDHURY, SERAJUL ISLAM. Shakespearer Meyera, Dhaka. Bangladesh: Oitijjhya, 2004.

EAGLETON, TERRY. "The witches are the heroines of the piece...". Macbeth. Ed. Alan Sinfield. London, England: MacMillan, 1992.

FRENCH, MARILYN. "Macbeth and Masculine Values". Macbeth, Ed. Alan Sinfield. London, England: MacMillan, 1992.

FREUD, SIGMUND. “The Character of Lady Macbeth”. Macbeth, Ed. Alan Sinfield. London. England: MacMillan, 1992.

HARDY, THOMAS. The Return of the Native. London, England: Penguin, 1994.

LAVINE, T.Z. From Socrates to Sartre: the Philosophic Quest. New York: Bantam, 1984.

"Life". 15 Aug. 2003. Stanford Encyclopedia of Philosophy. Metaphysics Research Lab, Stanford U. 14 Octob. $2013<$ http://plato.stanford.edu/entries/life/>

LONG, WILLIAM J. English Literature, Dhaka. Bangladesh: Friends' Book Corner, 2007.

MARLOWE, CHRISTOPHER. Doctor Faustus, Ed. Suroopa Mukherjee. Delhi. India: Worldview Publications, 2000.

MILLS, CHRISTOPHER. "The Relationship between Macbeth and Lady Macbeth". Critical Essays on Macbeth. Ed. Linda Cookson and Bryan Loughrey. Essex, England: Longman, 1988.

RUSSELL, BERTRAND. History of Western Philosophy, London: Routledge, 1996.

SHAKESPEARE, WILLIAM. Macbeth, Ed. A. R. Braunmiller. Cambridge UP, 1997.

STUMPF, SAMUEL ENOCH. Socrates to Sartre: A History of Philosophy, 2nd ed. New York: McGraw-Hill, 1975. 